BIBLIOGRAPHY

Lacarrère, J. L.-Electrodiaphakia. Klin. Monatsbl, f. Augenheilk., Vol. LXXXVIII, p. 788 (III), 1932.

Zimmerman, C.-Amer. Jl. of Ophthal., Vol. XV, p. 1001, 1932.

Lacarrère, J. L.-Our new method of intracapsular extraction of senile cataract. Electrodiaphakia. Arch. de Oftal. Hisp.-Amer., Vol. XXXII, p. 293 (III), 1932.

Davidson, M.-Amer. Jl. of Ophthal., Vol. XV, p. 1001, 1932.

Lacarrère, J. L.- Cataract extractions by means of the electrophake. Rev. Cubana de Oto-Neuro-Oftal., Vol. I, p. 149, 1932.

Wilde, A. G.-Amer. Jl. of Ophthal., Vol. XVI, p. 178, 1933.

Lacarrère, J. L.-Arch. de Oftal. Hisp.-Amer., Vol. XXXII, p. 293, 1932.

La extracción de la cataracta senil mediante nuestro metodo operatorio de "electrofaquia." La Medicina Iberia, Madrid, 1932.

Nuestra técnica operatoria de la cataracta por "Electrodiafaquia." Revista Oto-Neuro-Oftalinologia, Año 1932.

Ann. d'Ocul., Vol. CLXX, pp. 273-289, 1932.

A rchivos de Oftalmologia de Buenos-Aires, Vol. VII, pp. 323-334, 1932.

Nuestro procedimiento original de extraccion total de la cataracta senil.

La electrodiafaquia. Barcelona, 1932.
Arch. de la Facultad de Medicina de Zaragoza, Nov.-Dec., 1932.

Tobgy, A. F.-Bulletin of the Ophthalmological Society of Egypt, Vol. XXVI, Session 30, p. 20, 1933.

\title{
A VISUAL ACUITY TEST FOR MALINGERERS
}

\author{
BY \\ Lt.-Col. Sir J. N. Duggan, Kt., C.I.E., O.B.E., D.O.(Oxon.) \\ BОМВАY
}

THE malingerer in India is usually illiterate and ignorant. But he has all the more cunning to dodge the examiner and keep him on the fence. Besides, detection of malingerers is much hampered by the dearth of appliances which by systematic manipulation by the surgeon will certainly confuse the patient. This is especially so in India where the malingerer type often has an alert mentality that is quick to take advantage of the simplicity of most of the existing tests, and thus confound the legitimate suspicions of his examiner. I often had to spend long hours in detection of such malingerers, but never had the complete satisfaction of being convinced of their simulation. I have, therefore, longed for a test which could be used successfully with illiterate patients and, while convincing one of their malingering, would also help to determine their visual acuity fairly accurately to enable the surgeon to ascertain the percentage loss of vision. The test I have devised is capable of many variations of the positions and number of the openings in relation to the colours. Moreover, as the apertures are in Snellen sizes from 6/24 to $6 / 6$ it has the additional advantage of being in great measure a visual acuity test. The feature of the 
test is the multitude of variations. No less than four variations of each of the sizes from $6 / 36$ can be made quickly and without the knowledge of the patient. As will be seen in the photograph $\underset{\stackrel{\vec{m}}{\vec{m}}}{\overrightarrow{2}}$ the test consists of an internally illuminated box, the face of which is divided into four equal rectangles each containing coloured glasses, two of these being green, one red and one white. In front of this is placed one of a series of metal sheets in which are

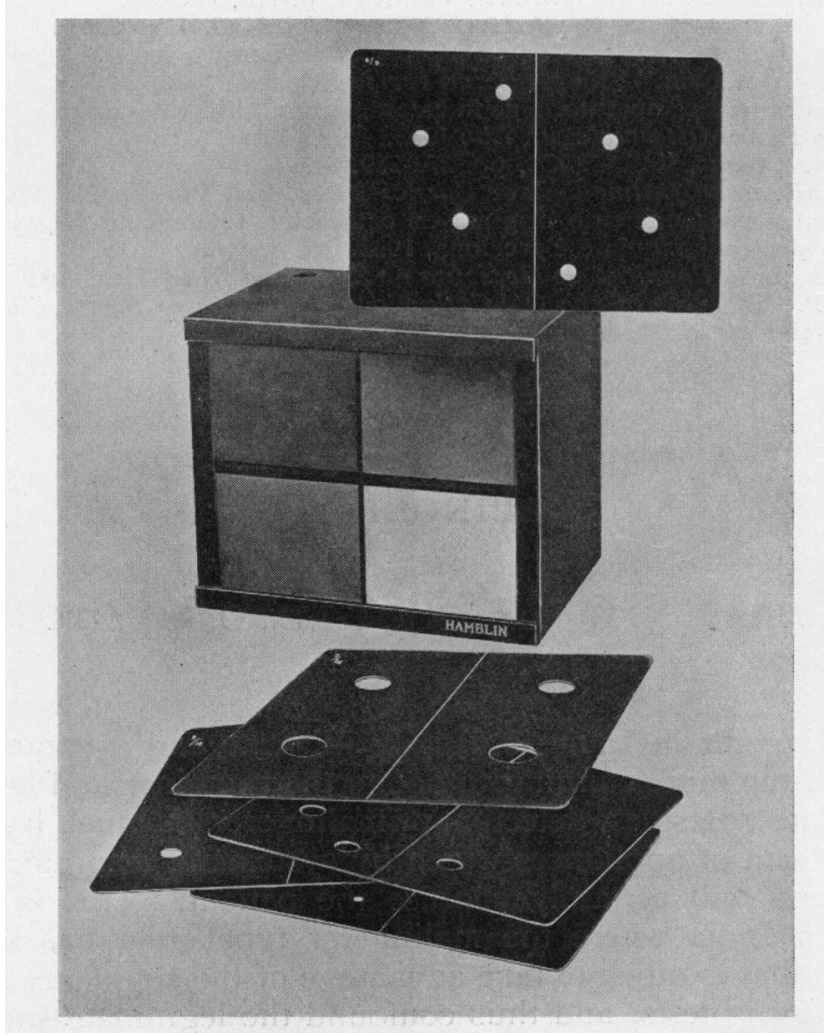

apertures so arranged that by varying the way in which it is $\frac{}{3}$ placed before the coloured squares (upright, upside down and $D$ back to front) as many as four different variations of the aperture positions are possible. The surgeon may make as many as 21 N variations quickly and in a great many different progressions. N Fore-knowledge of the surgeon's intentions or accurate guessing స్ల్ల on the part of the patient is thus rendered impossible, and a malingerer, of the most cunning type, is quickly detected. The test has been made for me by Theodore Hamblin, Ltd., of 15, Wigmore Street, London. 